\title{
An empirical examination of investor sentiment and stock market volatility: evidence from India
}

\author{
Haritha $\mathrm{P} \mathrm{H}^{1 *}$ and Abdul Rishad ${ }^{2}$
}

\author{
* Correspondence: haritha.ph2@ \\ gmail.com \\ ${ }^{1}$ Central University of Kerala, \\ Kasaragod, India \\ Full list of author information is \\ available at the end of the article
}

\begin{abstract}
Understanding the irrational sentiments of the market participants is necessary for making good investment decisions. Despite the recent academic effort to examine the role of investors' sentiments in market dynamics, there is a lack of consensus in delineating the structural aspect of market sentiments. This research is an attempt to address this gap. The study explores the role of irrational investors' sentiments in determining stock market volatility. By employing monthly data on market-related implicit indices, we constructed an irrational sentiment index using principal component analysis. This sentiment index was modelled in the GARCH and Granger causality framework to analyse its contribution to volatility. The results showed that irrational sentiment significantly causes excess market volatility. Moreover, the study indicates that the asymmetrical aspects of an inefficient market contribute to excess volatility and returns. The findings are crucial for retail investors as well as portfolio managers seeking to make an optimum portfolio to maximise profits.

Keywords: Investor sentiment, Stock market volatility, Principal component analysis, GARCH, Granger causality test
\end{abstract}

\section{Introduction}

There has been growing academic attention in the past decade on investors' sentiments and their potential impact on market performance. Investor sentiment is the expectation of market participants about the future cash flows (returns) and investment risk (De Long et al. 1990). Because traditional stock market theories comprehended market dynamics under the theoretical framework of the efficient market hypothesis (EMH) and random walk theory, they did not consider investor sentiment as an important aspect. However, they failed to explain the heterogeneous behaviour of investors in the capital market. Investors' sentiment is a vital aspect of the capital market, as it contributes to frequent fluctuations in the stock price and thus creates uncertainty about future returns on investments. In the past few decades, there have been radical changes in the Indian financial environment, especially in the basic structure-for example, shifting from a savings-oriented economy to an investment-oriented economy. These

(c) The Author(s). 2020 Open Access This article is licensed under a Creative Commons Attribution 4.0 International License, which permits use, sharing, adaptation, distribution and reproduction in any medium or format, as long as you give appropriate credit to the original author(s) and the source, provide a link to the Creative Commons licence, and indicate if changes were made. The images or other third party material in this article are included in the article's Creative Commons licence, unless indicated otherwise in a credit line to the material. If material is not included in the article's Creative Commons licence and your intended use is not permitted by statutory regulation or exceeds the permitted use, you will need to obtain permission directly from the copyright holder. To view a copy of this licence, visit http://creativecommons.org/licenses/by/4.0/. 
changes have increased heterogeneity in the composition of participants and impacted investors' risk-taking behaviour.

As per the EMH in classical financial theory, market participants exhibit rational risk aversion. Moreover, the information efficiency of the market does not allow participants to outperform the market (Fama 1965). The classical theory fails to explain the presence of systematic mispricing in the capital markets resulting from sentimental factors. Behavioural financial theories claim that irrational behaviour of noise traders and arbitrators causes a disparity in asset prices from their intrinsic (fundamental) values. Recent theoretical advances in behavioural finance and empirical evidence both have rejected the hypotheses of classical financial theory because of its assumption of rationality of agents in capital markets. In the previous decade, rational participants did not seem to have played a leading role in bringing the value of assets up to the then current value of anticipated cash flows (Baker and Wurgler 2007). Behavioural finance offers an alternative model that claims that economic phenomena can be better understood if the investors are accepted to not be entirely rational. In this context, the asset pricing not only includes the risk-related anticipated rates but also the impact of investor expectations on the returns. Behavioural finance explains the relationship between investment and the investor's psychology. Investor behaviour is reflected in the stock prices, and market fluctuations, which ultimately shape the market, are themselves shaped by the psychology of the investors. Baker and Wurgler (2006) argued that market sentiment creates a tendency for investors to be optimistic or pessimistic while speculating prices instead of deciding on fundamental factors.

Previous studies sought to detect the predictability of sentiments as a systematic risk factor valued as per certain conditions in the market. Studies from developed economies like the USA are far ahead in understanding the sentiment-related market dynamics (Barberis et al. 1998; Lee et al. 2002; Neal and Wheatley 1998). Academic study of investor sentiment in developing economies with rapidly growing capital markets is still in infancy. Previous research has mainly focused on the influence of investors' sentiment on investment returns, whereas the effect of sentiment on the conditional volatility structure of the market is less explored. Also, even among those studies that consider sentiment as a critical factor influencing the time-varying stock return, volatility and potential profitability relating to noise traders were the main aspects of focus. During the periods of high sentiment and low sentiment, noise traders act differently to keep their positions secure. During the high sentiment episodes, their participation and trading is more aggressive compared to that during a low sentiment episode. This is caused by naive and unaware noise traders' misjudgement of potential risk. Past academic studies about emerging economies have not explored such factors in-depth. The present study is an attempt to address the above-mentioned issues by using a market-oriented sentiment index. We developed an investors' sentiment index by using multiple sentiment yardsticks mentioned by Baker and Wurgler (2006). Considering the investors' sentiments' contribution to volatility in emerging markets, the current study aimed to establish new empirical evidence to add a more comparative dimension to the existing literature. The findings can help market participants to understand the role of investor sentiment in the determination of conditional volatility of the market and to take decisions to optimise the portfolio.

This study developed the aggregate sentiment index (ASI) from market-oriented sentimental factors such as trading volume, put-call ratio, advance-decline ratio, market 
turnover, share turnover and number of initial public offers (IPOs) in the period. The use of a constructed sentiment index under the GARCH framework to estimate the association between stock market volatility and investor sentiment makes this study different from existing studies. The findings indicate the persistence of volatility in market indices. Such persistent connection between the sentiment index and stock volatility suggests that investor sentiment is one of the most crucial determinants of Indian stock market volatility.

\section{Theoretical background}

According to the conventional theory of 'market noise' proposed by the Black (1986), noise traders operate on noisy signals in financial markets and balance both the systematic and non-systematic risk of an asset. According to this theory, noise makes markets inefficient to some extent and prevents investors from benefitting from inefficiencies. The significance of sentimental factors in asset pricing theories is substantiated by empirical literature from developed economies. The question of how irrational beliefs held by investors affect the market through asset pricing and expected returns is explained in behavioural finance theories. The theoretical model developed by De Long et al. (1990) explained this phenomenon as 'Some investors, denominated noise traders, were subject to sentiment - a belief about future cash flows and risks of securities not supported by economic fundamentals of the underlying asset(s) - while other investors were rational arbitrageurs, free of sentiment. The irrational beliefs were caused by noise, interpreted by the irrational traders as information, thus the term noise traders.'

Theoretically, noise is part of irrational behaviour; the irrational traders consider noise as information. Interestingly, proponents of an efficient market claimed that noise traders were exploited by rational arbitrageurs who drove prices towards fundamental equilibrium values. Thus, noise was a reaction of noise traders to the activities of rational arbitrageurs that caused overpricing or underpricing of stocks during periods of high and low sentiment (Lemmon and Portniaguina 2006; Baker and Wurgler 2006). Researchers have been unable to satisfactorily explain the interaction between rational and irrational investors. The continuing debate on this issue significantly contributes to the literature but concentrates mainly on the role of noise traders in anticipated asset yields and volatility of return. It is not understood how the market reacts to noise, which is caused by a large number of small events. This behaviour can be observed among investors from advanced economies because they believe that systematic risk and return anomaly is associated with irrational investment behaviour (Brown and Cliff 2004; Qiu and Welch 2006; Lemmon and Portniaguina 2006). With this theoretical background, our study examines the role of irrational feelings of investors and their impact on the volatility of the Indian capital market.

\section{Literature review}

The development of behavioural finance theories triggered a discussion on the impact of investor sentiment on asset returns in the integrated stock market. According to theoretical and empirical research, investor sentiment strongly influences stock prices with inevitable consequences on portfolio selection and asset management, as psychological differences of heterogeneous investors have implications on the pricing of assets in the market. The influence of investor's sentiment in asset price volatility is widely 
described as a combination of investors' reaction to the current market situation and unjustified expectation of the future cash flows (Baker and Wurgler 2006, 2007).

As a psychological factor, it is not easy to estimate investors' sentiment because of their subjective and qualitative nature. However, different proxies have been used to measure sentiment. These indicators of the sentiment index are classified as indirect and direct measures. In direct measures, researchers measure the individual investor sentiment via surveys and polling techniques. They are highly sampling-dependent, and the chances of sampling errors are high. Moreover, they may not be able to give a broad picture of the prevailing sentiment. Indirect measures use market-determined sentiment proxies, such as trading volume, turnover volatility ratio, put-call ratio, advance-decline ratio, market turnover and share turnover for measuring the same. They posit that investors' sentiment are reflected in the structure and breadth of the market and understanding these dynamics helps to capture the irrational aspects of the market. The consistent and theoretically comprehensible nature of the sentiment index has led to its wide adoption (Baker and Wurgler 2006; Brown and Cliff 2004; Chen et al. 1993; Clarke and Statman 1998; DeBondt and Thaler 1985; Elton et al. 1998; Fisher and Statman 2000; Lee et al. 2002; Neal and Wheatley 1998; Sias et al. 2001). According to Zhou (2018), investor sentiment indicates the distance of the asset's value from its economic bases. This can be measured from different sources, such as official documents, media reports and market surveys. Mushinada and Veluri (2018) used trading volume and return volatility for understanding the relationship between sentiments and returns. Their findings showed that post-investment analysis was essential to correct errors in previous behavioural estimations. Market participants' behaviour is heterogeneous because of the risk-return expectation, and it creates noise in the market. These findings contradict with the premises of the efficient market hypothesis that postulate that markets turn information efficient when investors behave rationally.

In the past few decades, empirical studies across the globe have investigated the connection between investors' sentiment and stock returns for understanding and substantiating theories of market inefficiency (Brown and Cliff 2004; Fisher and Statman 2000). Chi et al. (2012) examined the impact of investor sentiment on stock returns and volatility by using mutual fund flows as an investor sentiment proxy in the Chinese stock market. They found that investor sentiment has a great impact on stock returns. The relationship between stock market volatility and investor sentiment has also been reported as statistically significant. Supporting these findings, Zhou and Yang (2019) stated that the construction of a theoretical model of stochastic investor sentiment influences investor crowdedness and also affects asset prices. Their result indicated that optimistic (pessimistic) expectations of investors can move asset prices above (below) the basic value. By examining the long-term association between investor sentiment in the stock and bond market, Fang et al. (2018) showed that the index of investor sentiment is positively associated with market volatility. Contradicting the fundamental tenets of the efficient market hypothesis, Shiller (1981) argued that investors are not completely rational, which could affect market prices aside from fundamental variables. Wang et al. (2006) noted that the sensitivity of investor sentiments to the information flow affected both market return and volatility. Chiu et al. (2018) found a positive relationship between investor sentiment, market volatility and macroeconomic variables. Jiang et al. (2019) constructed the fund manager's sentiment index as 
a predictor of aggregate stock market returns. They found that when managers had a high level of sentiment, it caused a reduction in overall income surprises from total investment. Li (2014) pointed out that the sentiment index has strong predictive power for Chinese stock market returns. Retail investors' attention will help to mitigate the crash risk, as the retail investors' attention will not allow any irrational or noise traders to overrun the rational market participants (Wen et al. 2019).

Verma and Verma (2007) studied the role of retail and noise traders in price volatility to yield similar results. Verma and Soydemir's (2009) empirical examination of the rational and irrational investors' impact on market prices also supported the previous finding. They discovered that individual and institutional investors' feelings influenced the market. Further evidence shows that the response of the market to volatility is not homogeneous; it is heterogeneous depending on the variations in shareholder sentiment. These findings are validated by Gupta (2019) who found that sentiments of fund managers are a stronger predictor than the returns, when it comes to forecasting volatility. Yang and Copeland (2014) found that the investor sentiment index has a long-term and short-term asymmetrical impact on volatility. They concluded that bearish sentiment is associated with lower returns than bullish sentiment, which accelerates market return. This shows that the bullish feeling has positive effects on short-term volatility, whereas in the long-term, it has a negative effect on volatility. These findings agree with the findings discussed by Qiang and Shue-e (2009), namely that positive and negative sentiment create different impacts on stock price variation. Baker et al. (2012) constructed investor sentiment indicators of six nations but because of the disintegration of different markets owing to the heterogeneous behaviour of investors across the globe, the indicators were not viable. Other studies have reported that investors' sentiments are driven by overall funding patterns irrespective of the investor being individual or institutional (Baker and Wurgler 2000; Henderson et al. 2006). Investors' sentiment has a mutual relationship with the expected return of public bonds and the expected return from the stock market (Bekaert et al. 2010).

In the context of the Indian stock market, Sehgal et al. (2009) discussed the fundamental aspects of investor sentiment and its relationship with market performance. They identified several factors that might act (individually and together) as indicators of market behaviour and investor sentiments' influence on market behaviour. The authors used macroeconomic factors such as real GDP, corporate profits, inflation, interest rates and liquidity in the economy and market-based factors such as the putcall ratio, advance-decline ratio, earnings surprises, the price to earnings ratio and price to book value as potential factors to explain the underlying investor sentiment at the aggregate market level. They also suggested the development of a sentiment index based on these macroeconomic and market indicators. Using some of these indicators, Dash and Mahakud (2013) examined the explanatory power of an index of investor sentiment on aggregate returns. They found a significant relationship between the investor sentiment index and stock returns across industries in the Indian stock market. Rahman and Shamsuddin (2019) studied the excess price ratio and its influence on investor sentiment and found that the price to earnings ratio increased with a rise in investors' sentiment. Kumari and Mahakud (2016) and Chandra and Thenmozhi (2013) studied the impact of investor sentiment in the Indian capital market. They found a positive relationship between investor sentiment and market volatility. Verma and 
Verma (2007) showed that investor sentiment has a positive impact on asset return, but it makes an adverse impact on individual and institutional investors owing to market volatility. Aggarwal and Mohanty (2018) studied the impact of the investor sentiment index on the Indian stock market and found that there is a positive relationship between stock returns and investor sentiments. However, most of these studies focused on the general effect of investors' sentiment on stock returns. Such an approach restricts our understanding of the phenomenon of investors' sentiment and its influence on market dynamics to a single dimension. In the present study, we explored the role of investor sentiment in determining excess market returns and volatility.

\section{Data and variables}

Being a qualitative factor, it is not easy to quantify the market behaviour of investors. Past studies have used multiple ways to measure investors' sentiment. Some studies have relied on media reports, events and other publicly available documents to collect information on investor behaviour, and other studies have conducted surveys among investors for the same. Some other researchers have used market-based indicators such as price movements and trading activities for constructing sentiment indexes. A few researchers have used single variables as an indicator of investor sentiment. For instance, Mushinada and Veluri (2018) used trading volume as an indicator of investor sentiment. Using a single variable may not be sufficient to explain market sentiments because there are multiple factors that cause variation in these single variable proxies. Latest studies have constructed the sentiment index by using multiple market-based indicators that directly reflect the participants' behaviour. Following Baker et al. (2012), this study employed multiple market-based indicators for constructing the sentiment index for the period from January 2000 to December 2016. We used the monthly average closing price of the NIFTY 50 (Nifty) stock index to measure market volatility and return. The diversified market representation of the Nifty index over the other benchmark BSE SENSEX (Sensex) motivated us to select the former. The study used monthly data because of the scarcity of high-frequency data on market-related indicators. The data was collected from the official websites and various reports of the National Stock Exchange, Reserve Bank of India and Securities and Exchange Board of India.

The study employed Bollerslev (1986) generalized autoregressive conditional heteroskedastic model (GARCH) to measure volatility using the conditional variance equation and to capture the dynamics of volatility clustering. This helped us to examine how the investors' sentiment reacts to market volatility. This model helps verify whether the investors' shocks are persistent or not. For the serial correlation, this study used the autoregressive conditional heteroskedasticity-Lagrange multiplier (ARCH-LM) of Engle and Ng (1993), autoregressive conditional heteroskedasticity (ARCH) test of Engle (1982) and Mcleod and Ll (1983) tests for the estimation of models. We also employed the Granger causality test to check the direction of causality between sentiment and market volatility.

\section{Construction of investors' sentiment index}

The present study adopted the framework developed by Baker et al. (2012) to construct the investors' sentiment index. It considered six variables: trading volume, put-call 
ratio, advance-decline ratio, market turnover, share turnover and the number of IPOs. The number of IPOs was defined as the total number of IPOs during the period. Baker et al. (2012) argued that firms try to procure more capital when the market value of the firm is high and repurchase their shares when the market value is low. The intention is to take advantage of the market sentiment until it reaches the fundamental value. In a bullish market, new issue of shares will transfer wealth from new shareholders to the company or to the existing shareholders. This market timing hypothesis suggests that higher (lower) value or number of IPOs means that the market sentiment is bullish (bearish) (Baker and Wurgler 2006). The number of IPOs reflects the market pulse; hence, they can be considered as an important component of the sentiment index.

The share turnover ratio is one of the conventional yardsticks for measuring the liquidity position, which reflects the active participation of traders and investors in the market. It is the ratio of the total value of shares traded during the period to the average market capitalization for the period. Turnover is vital in gauging investors' sentiment in the market. Irrational investors actively participate in the market when they are optimistic and accelerate the volume of turnover (Baker and Stein 2004). Theoretically, the relationship between market returns and turnover is expected to be negative (Jones 2001). The presence of high turnover ensures liquidity and reduces the chances of abnormal returns.

Market turnover (MT) is the ratio of trading volume to the number of shares listed on the stock exchange. Market sentiment can be sensed from the turnover of the market because turnover will be low in bearish markets and high in bullish markets (Karpoff 1987). Small turnover is usually preceded by a price decline, whereas high turnover is associated with an increase in price (Ying 1966). Thus, the turnover information is a significant component of measuring the sentiment of market participants.

The advances and declines ratio (ADR) is a market-breadth indicator that analyses the proportion between the number of advancing shares and declining shares. The increasing (decreasing) trends in the ADR confirm the upward (downward) trend in the market (Brown and Cliff 2004). Generally, the ADR ratio is expected to be positive because investors' sentiment makes the market active. Thus, the ADR ratio helps to recognise the recent trend and can be used as an indicator of market performance.

The put-call ratio (PCR) is another indicator to measure the dynamics of the secondary market. This sentiment indicator is measured as the ratio between transactions on all the put options and the call options on Nifty. A higher (lower) ratio indicates a bullish (bearish) sentiment in the market. Incorporating PCR to measure the aggregate sentiment index yields accurate results because it reflects the expectations of market participants. When market participants expect a bearish trend, they try to shield their positions. When trade volumes of put options are higher relative to the trade quantity of call options, the ratio will go up (Brown and Cliff 2004; Finter and Ruenzi 2012; Wang et al. 2006). This derivative market proxy is considered as an indicator of a bullish trend because the bearish market PCR will be small (Brown and Cliff 2004).

The trading volume (TV) is a key variable for constructing the sentiment index. It is measured as the monthly average of the Nifty daily trade volume. Frequent trades in an active market increase the volume and create liquidity in the market. Therefore, researchers have used market turnover as a proxy for investor sentiment (Qiang and Shue-e 2009; Zhu 2012; Li 2014; Chuang et al. 2010). The present study considered TV as one of the indicators of market sentiment. 
Macroeconomic factors that are often flashed in the media tend to influence investor sentiment quite significantly. Factors like the levels of inflation, corporate debt, economic growth rate and foreign exchange rate and reserves tend to affect the behaviour of market participants to a certain extent. Therefore, this study used variables such as the exchange rate, Wholesale Price Index (WPI), Index of Industrial Production (IIP), Net Foreign Institutional Investment (FII) and Term Spread (TS) to measure the intensity of aggregate investor sentiment on market volatility.

\section{Unit root tests}

Ensuring the stationarity of the variables is necessary for consistent estimators. This study used the augmented Dickey-Fuller test (ADF) (Dickey and Fuller 1981) to analyse the presence of unit roots in the time series properties of each variable. Table 1 shows the results of unit root analysis using the ADF test. Unit root tests were run with the linear trend and at levels and intercept. The result shows that all variables expect MT are stationary at level. MT was converted to stationarity by taking the first difference.

\section{Principal component analysis}

Principal component analysis (PCA) is a multivariate method in which several interconnected quantitative dependent variables describing the observations are analysed. PCA aims to find and extract the most significant information from the data by compressing the size and simplifying the data without losing the important information (Abdi and Williams 2010). It consists of several steps for conducting the linear transformations of a large number of correlated variables to obtain a comparatively few unrelated elements. In this way, information is clustered together into narrow sets and multicollinearity is eliminated. The principal goal of PCA is to summarize the indicator data through a common set of variables as efficiently as possible.

$$
\text { IASI }=0.811 \text { ADRt }-1+0.565 \text { MT-0.282IPOS-0.103PCR }+0.459 \text { ST-0.603TVt-1 }
$$

First, the six orthogonal sentiment proxies and their first lags were used as factor loadings to calculate the raw sentiment index. The study started with estimating the initial principal component of the six indicators and their lags, which gave a first-stage index with 12 loading factors, namely the six proxies and their lags. Then, we calculated the correlation between the initial index and the current and lagged values of the indicators. Finally, we estimated the sentiment as the first principal component of the correlation matrix of six variables, which were the respective proxy's lead or lag. We chose whichever had a higher

Table 1 Unit root tests

\begin{tabular}{ll}
\hline Variables & Stationarity (at Level) \\
\hline ADR & $-2.9922^{\mathrm{a}}$ \\
MT & -2.3387 \\
IPO & $-2.5932^{\mathrm{a}}$ \\
PCR & $-2.9390^{\mathrm{a}}$ \\
TV & $-2.6548^{\mathrm{a}}$ \\
ST & $-3.7966^{\mathrm{a}}$ \\
\hline
\end{tabular}

${ }^{\mathrm{a}} 1 \%$ level of significance 
correlation with the first-stage index to rescale the coefficients so that the index had unit variance (Table 2). This process yielded a parsimonious index.

\section{Investors' sentiment and stock market volatility}

Following the theoretical and empirical models proposed by Baker and Wurgler (2007), Brown and Cliff (2004) and Baker et al. (2012), this study used market-related indicators for the construction of the investor sentiment index in the initial stage. This study used six indirect proxies to create the sentiment index by considering the first principal component and the lagged components of the variable. The first principal component explains the sample's variance. Researchers have argued that certain proxies take longer periods to reflect the investors' sentiment. Therefore, the present study followed the approach of Baker and Wurgler (2006) and Ding et al. (2017) to reflect the investors' sentiment accurately and to assess the PCA with levels as well as their lags to find the main factors.

The GARCH $(1,1)$ model was used to estimate the impact of sentiment on market volatility and stock returns. The GARCH model helps analyse the volatility characteristics of the datasets, especially for financial data, as it has the unique characteristics of heteroscedasticity and volatility clustering (Fig. 1). The specific character of financial time series data limits the use of conventional econometrics models to estimate the parameters. The GARCH model helps to capture volatility clustering and to manage issues of heteroskedasticity.

Stock market volatility can be estimated in two ways: with the help of marketdetermined option prices or by time series modelling. Non-availability of option prices led us to choose the time-series method. There are multiple indices available to measure the dynamics of the Indian capital market. Among them, Nifty, which consists of 50 companies from different sectors, and Sensex, which covers 30 companies, are prominent. Inclusion of diversified sectors and wider market coverage (market capitalisation) motivated us to select Nifty as the indicator for measuring market volatility. The indicator of market returns and the aggregate sentiment index showed volatility clustering (Fig. 2), and the heteroskedastic behaviour was confirmed through the ARCH-LM test. This satisfied the prerequisites for estimating the GARCH model.

The GARCH $(p, q)$ model, introduced by Engle (1982) and Bollerslev (1986), can be expressed as follows:

$$
\begin{gathered}
r_{t}=c_{0}+\gamma r_{t-1}+\varepsilon_{t}, \\
\varepsilon_{t} \mid I_{t-1} \sim N\left(0, h_{t}\right), \\
h_{t}=\omega+\alpha \varepsilon_{t-1}^{2}+\beta \sigma_{t-1}^{2},
\end{gathered}
$$

Table 2 Cumulative proportion of sentiment proxies

\begin{tabular}{llllll}
\hline Number & Value & Difference & Proportion & $\begin{array}{l}\text { Cumulative } \\
\text { Value }\end{array}$ & $\begin{array}{l}\text { Cumulative } \\
\text { Proportion }\end{array}$ \\
\hline 1 & 2.048 & 0.509 & 0.344 & 2.046 & 0.344 \\
2 & 1.539 & 0.538 & 0.257 & 3.586 & 0.598 \\
3 & 1.002 & 0.225 & 0.167 & 4.588 & 0.765 \\
4 & 0.779 & 0.324 & 0.136 & 5.367 & 0.895 \\
5 & 0.457 & 0.281 & 0.076 & 5.824 & 0.971 \\
6 & 0.177 & - & 0.029 & 6 & 1 \\
\hline
\end{tabular}




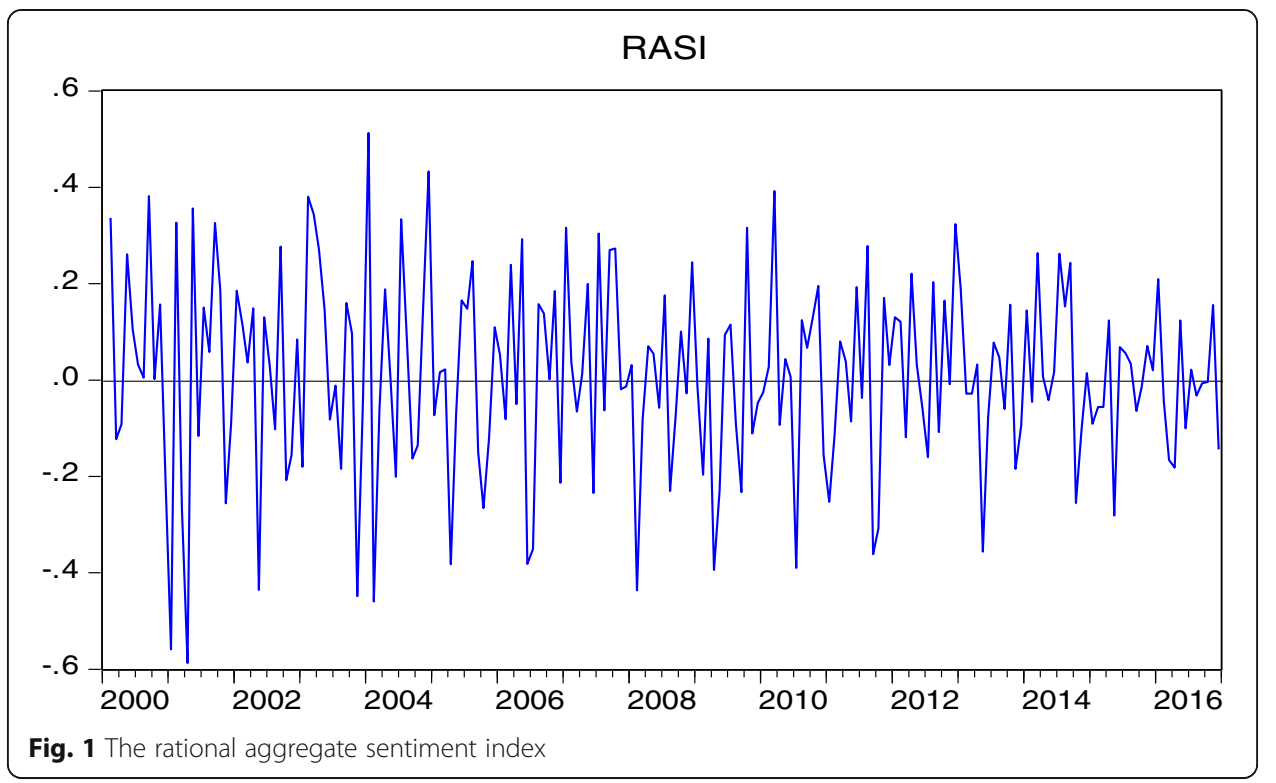

where $r_{t}$ is the $\log$ Nifty return (the positive value of $r_{t}$ indicates a bullish trend in the market, and the negative value shows a bearish trend in the market). It is calculated by. $r_{t}=\frac{P_{1}-P_{0}}{P_{0}}$, where $\mathrm{P}_{0}$ and $\mathrm{P}_{1}$ represent the price at time $\mathrm{t}-1$ and $\mathrm{t} . \gamma$ is the coefficient of the lagged value of the Nifty return $\left(r_{t-1}\right) \cdot c_{0}$ is the constant of the mean equation; $\omega$ is the constant in the variance equations; and $\varepsilon_{t}$ is the error term. $I_{t-1}$ represents the information available to the market participants. $\varepsilon_{t-1}^{2}$ is the ARCH term and $\sigma_{t-1}^{2}$ is the GARCH term that explains the instantaneous variance at time $t-1 . \alpha+\beta>1 \beta \geq 0$, which shows the persistence of volatility. A value close to 1 indicates the persistence of volatility and indicates a low level of mean reversion in the system. By increasing the

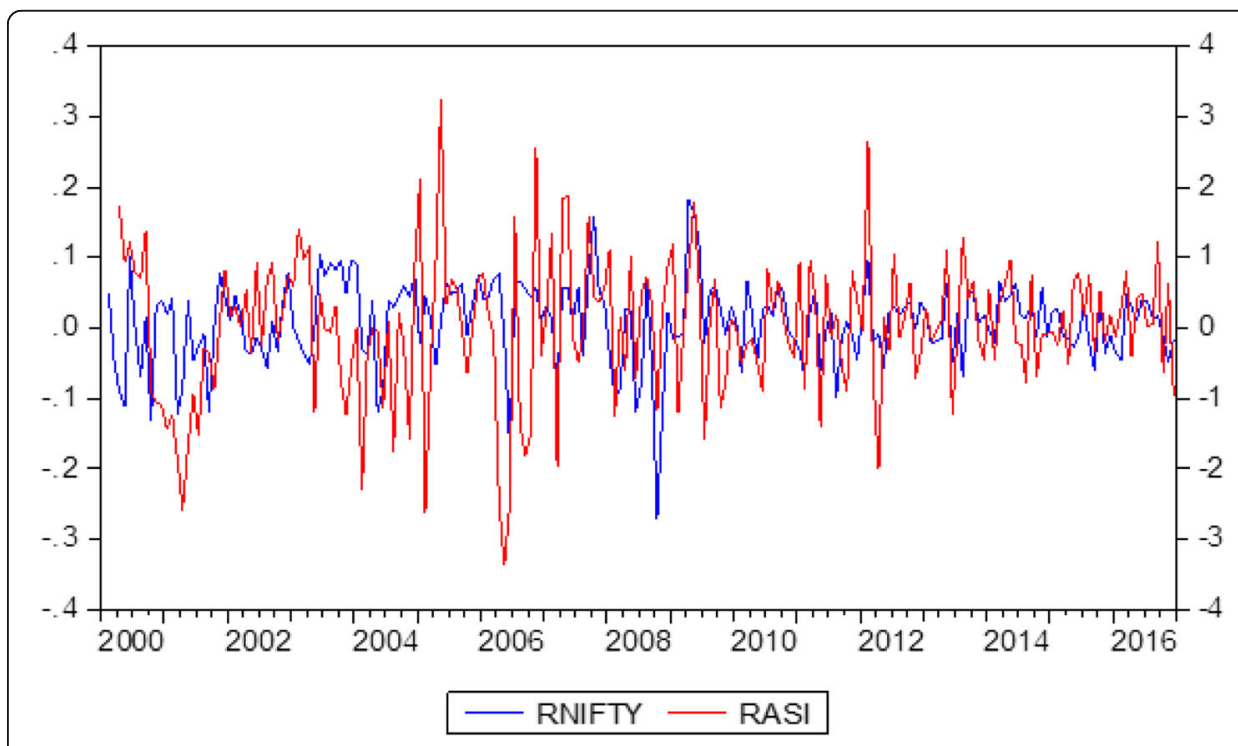

Fig. 2 Investors' sentiment and stock index return 
number of the ARCH and GARCH terms, the model can be generalized to a GARCH $(\mathrm{p}, \mathrm{q})$ model. For a well-specified GARCH model, $\omega>0, \alpha>0$ and $\beta \geq 0$ should be satisfied.

We modified the basic GARCH model by incorporating a sentiment variable in the equation,

$$
\begin{gathered}
r_{t}=c_{0}+\gamma \operatorname{Sent}_{t}+\varepsilon_{t}, \\
\varepsilon_{t} \mid I_{t-1} \sim N\left(0, h_{t}\right) \\
h_{t}=\omega+\delta \operatorname{Sent}_{t}+\alpha \varepsilon_{t-1}^{2}+\beta \sigma_{t-1}^{2}
\end{gathered}
$$

where $\delta$ represents the coefficient of the sentiment index.

\section{Empirical results}

The estimated result of the GARCH $(1,1)$ model is presented in Table 3. The coefficients of the ARCH $(\alpha)$ and GARCH terms $(\beta)$ are statistically significant and different from zero. In addition, the sum of $\alpha+\beta$ is close to unity. This indicates the high persistence of volatility, that is, the mean reversal process is very slow because of the persistent shocks. The result of the ARCH-LM test indicates the absence of further ARCH effects, which means the model captures the ARCH effects. The statistically significant coefficient of $\mathrm{Q}$ and $\mathrm{Q}^{2}$ at the 20th lag indicates the absence of further autocorrelation in the model.

Sentiment is a crucial element that directly influences market behaviour. The conventional capital asset pricing model theory states that investors should be rewarded according to their risk-taking behaviour. However, the impact of sentiment on market volatility may cause market uncertainty and lead to less returns. If the market participants fail to earn a market risk premium for their expected volatility, they will move away from the market, which further causes volatility in the market. This vicious circle may cause a bearish trend and languid growth and development of the market. The conditional volatility graph shows that the impact of negative sentiment is higher than that of positive sentiment. This indicates that when sentiments are positive, investors actively participate in the market with the expectation of higher returns. However, this causes more speculative activities in the markets and may cause overvaluation of scrips.

Table 3 Estimated GARCH model

\begin{tabular}{ll}
\hline Variables & Coefficients \\
\hline$c_{0}$ & $72.058(0.000)$ \\
$\gamma$ & $0.294(0.013)$ \\
Variance equation & \\
$\omega$ & 1.748 \\
$a$ & 0.296 \\
$\beta$ & 0.459 \\
$\delta$ & 0.574 \\
Q (20) & $27.084(0.133)$ \\
$Q^{2}(20)$ & $24.658(0.215)$ \\
ARCH LM & $0.036(0.852)$ \\
SIC & 4.728 \\
Hannan-Quinn criterion & 4.669
\end{tabular}


In contrast, during the dominance of negative sentiments, investors move away from the market because of the negative expectation of market returns. Therefore, it can be theorised that during positive sentiment, companies explore the opportunity to enter the market through IPOs. Similarly, dividend declaration, bonus issue and a rights issue also trigger positive sentiments.

\section{Conditional volatility}

The conditional variance graph from the GARCH $(1,1)$ model shows the dynamics of market volatility of the Nifty returns (Fig. 3). Up to May 2008, volatility was high, though it can be deemed as moderate when compared to that during the subprime crisis period. During this period, volatility increased exponentially, and this trend continued up to February 2010. Later, the volatility reduced substantially.

\section{Granger causality test}

The Granger causality test examines the direction of cause among different series (Granger 1969). A time series $x_{t}$ Granger-causes another time series $y_{t}$ if series $y_{t}$ can be predicted with better accuracy by using the past values of $x_{t}$ rather than by not doing so. This study examined the causal relationship between the sentiment index (Sent) and stock market return. Tests between the aggregate sentiment index and stock returns were modelled for understanding the leading and the lagging variables. We found that investors' sentiment leads to volatility of the market returns. However, volatility in the returns does not cause sentiment (Table 4).

De Long et al. (1990) pointed out that noise traders' pressure in a market with a strong bullish sentiment on the price to move beyond the fundamental value causes a drop in the expected return. However, if bullish noise traders dominate the market, it causes a rapid upward movement in the market prices because of the upsurge in demand for the high-risk scrips. The expected level of market risk will be higher, creating a 'hold more' effect because of the expectation of higher returns. The intensity

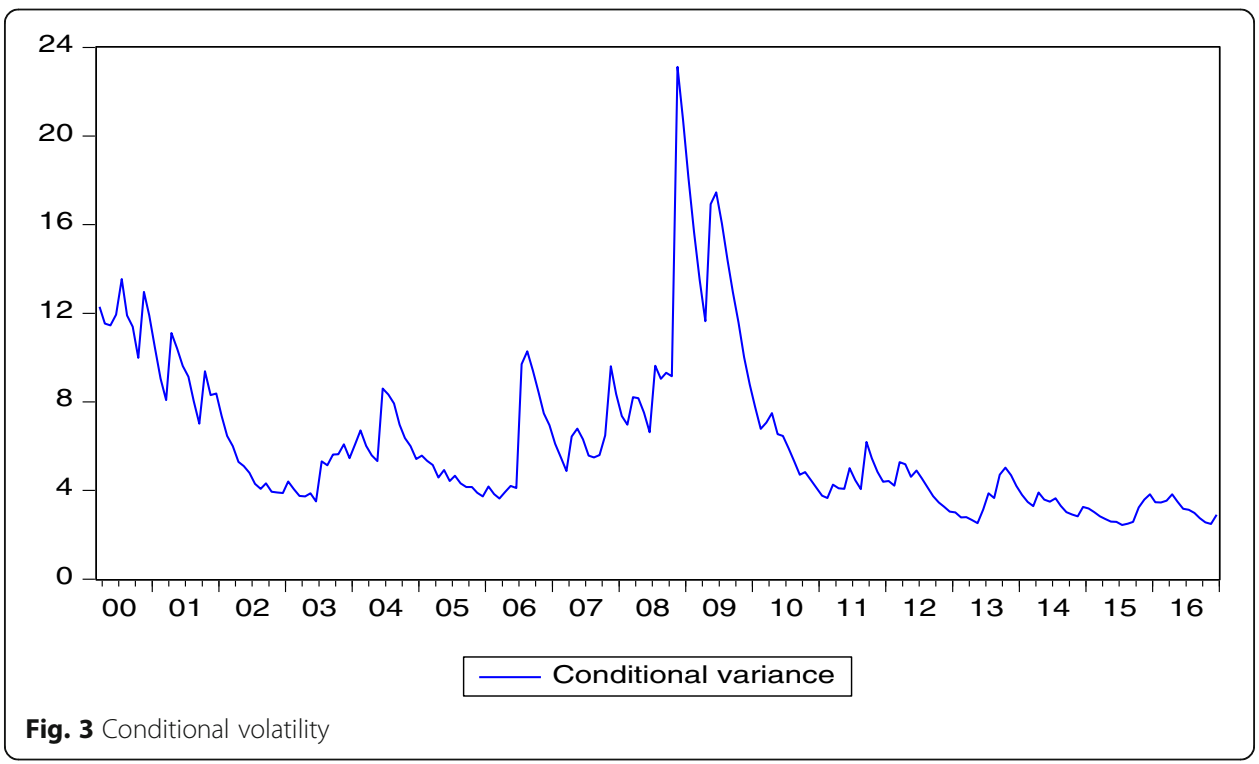


Table 4 Granger causality test

\begin{tabular}{lll}
\hline Null Hypothesis & F-Statistic & $p$ Value \\
\hline LOG_RETURN does not Granger cause RASI1 & 0.619 & 0.539 \\
RASI1 does not Granger cause LOG_RETURN & 2.643 & $0.074^{\text {a }}$
\end{tabular}

${ }^{\mathrm{a}}$ Significant at the $10 \%$ level

of sentiments on stock returns closely depends on the effect that dominates the market expectation. The unidirectional causality of sentiments to volatility indicates that the price-pressure effect (noise traders' pressure on prices reduces the expected return) dominates the market and that noise traders benefit during episodes of a high sentiment index. This way, sentiment leads to volatility. However, once the noise traders start making profit, their expectation on return and risk will increase. Thus, it may not create a reverse causality in a developing market because of information inefficiency. In another way, it can be explained that when investors' irrational sentiment is positive, their expectation on return is also positive. This may lead to speculative activities on their part to exploit the situation, exciting them to invest more. This leads to volatility in the market. On the other hand, market uncertainty causes withdrawal of market makers and encourages investors to stay inactive because of the uncertain expectation on the return in a risky market. Moreover, in such a situation, investors are always concerned about fundamentally induced equilibrium prices that give the fair value of assets. Following the arguments of Wen et al. (2019), retail investors should be more attentive in collecting information to minimise their information asymmetry for managing their potential risk.

\section{Conclusion}

This research provides a comprehensive examination of the impact of investor sentiment on stock market volatility. The study constructed a sentiment index by using a linear combination of different-market oriented proxies weighted using principal component analysis. The study found an asymmetrical relationship when the sentiment index was decomposed into positive and negative sentiment. The positive sentiment index has a positive effect on excess market return, but the intensity of negative sentiment is less on negative returns. These results imply that when investors are more optimistic about the market generating excess returns, their extreme optimism leads to more speculative activities that tempt them to invest even more. The study also found persistency of market volatility and the sentiment index, which shows the contemporaneous impact on sentiment and excess market returns. The findings reveal that investors consider the market as weak-efficient. This shows that the efficient market hypothesis may not be sufficient in explaining the market behaviour of emerging markets like India. The results indicate the scope for arbitration in the Indian market and thus invalidate the explanation of efficient market volatility in India. This further indicates a deviation from a random walk, but it is difficult to predict the volatility of the market sufficiently to produce excess returns.

The results help to understand the role of non-fundamental factors in driving the Indian equity market away from a fundamentally oriented equilibrium and in influencing the risk-return perception. They also show that sentiment is relatively correlated with unexpected stock returns, and the correlation differs significantly over time. This 
contradicts with the traditional capital market theories and supports the behavioural theories on capital markets. Proper examination of the market sentiment helps investors and fund managers decide their entry and exit points for investment. By taking the investor sentiment into account as a significant determinant of stock market volatility in asset price models, investors can enhance their portfolio performance. The results can also help policymakers' efforts to stabilize stock market volatility and uncertainty in order to protect investors' wealth and attract more investors. Therefore, future research should aim to develop investors' sentiments from available high-frequency data by incorporating additional comprehensive investor sentiment factors to reflect real-time information.

\section{Abbreviations}

IASI: Indian Aggregate Sentiment Index; GDP: Gross domestic product; PE Ratio: Price to earnings ratio; GARC $\mathrm{H}$ : Generalized autoregressive conditional heteroskedastic model; ARCH-LM: Autoregressive conditional heteroscedasticity-Lagrange multiplier; PCR: Put-call ratio; PCA: Principal component analysis; IPO: Initial public offer

\section{Acknowledgements}

Not applicable.

\section{Authors' contributions}

The authors analyze the role of irrational investor sentiment in determining Indian stock market volatility using monthly information from India's National Stock Exchange between June 2000 and December 2016. Sentiment index with the assistance of principal component analysis was developed using market-related implicit indices. Further, this sentiment index was modelled in the GARCH and Granger Causality framework to analyses its contribution to volatility. The results show that irrational sentiment significantly causes excess market volatility. Moreover, the study reveals that the asymmetrical aspects of an inefficient market contribute to excess volatility and returns. The findings reveal that investors consider the market as weak-efficient. This shows that the efficient market hypothesis may not be sufficient in explaining the market behaviour of emerging markets like India. The author(s) read and approved the final manuscript.

\section{Funding}

Not applicable.

Availability of data and materials

Not applicable.

\section{Competing interests}

Not applicable.

\section{Author details}

${ }^{1}$ Central University of Kerala, Kasaragod, India. ${ }^{2}$ Central University of Himachal Pradesh, Dharamsala, Himachal Pradesh, India.

Received: 29 August 2019 Accepted: 18 August 2020

Published online: 12 October 2020

\section{References}

Abdi H, Williams LJ (2010) Principal component analysis. Wiley Interdiscip Rev Comput Stat 2(4):433-459

Aggarwal D, Mohanty P (2018) Do Indian stock market sentiments impact contemporaneous returns? S Asian J Bus Stud 7(3): 332-346

Baker M, Stein JC (2004) Market liquidity as a sentiment indicator. J Financ Mark 7(3):271-299

Baker M, Wurgler J (2000) The equity shares in new issues and aggregate stock returns. J Financ 55:2219-2257

Baker M, Wurgler J (2006) Investor sentiment and cross-section of stock returns. J Financ 61(4):1645-1980

Baker M, Wurgler J (2007) Investor sentiment in the stock market. J Econ Perspect 21:129-152

Baker M, Wurgler J, Yuan Y (2012) Global, local, and contagious investor sentiment. J Financ Econ 104(2):272-287

Barberis N, Shleifer A, Vishny R (1998) A model of investor sentiment. J Financ Econ 49(3):307-343

Bekaert G, Baele L, Inghelbrecht K (2010) The determinants of stock and bond return comovements. Rev Financ Stud 23 : $2374-2428$

Black F (1986) Noise. J Financ 41(2):529-543

Bollerslev T (1986) Generalized autoregressive conditional heteroskedasticity. J Econ 31:307-327

Brown GW, Cliff MT (2004) Investor sentiment and the near-term stock market. J Empir Financ 11(1):1-27

Chandra A, Thenmozhi M (2013) Investor sentiment, volatility and stock return comovements. Volatility and Stock Return Comovements

Chen N, Kan R, Miller M (1993) Are the discounts on closed-end funds a sentiment? index? J Financ 48:795-800

Chi L, Zhuang X, Song D (2012) Investor sentiment in the Chinese stock market: an empirical analysis. Appl Econ Lett 19(4): $345-348$ 
Chiu CWJ, Harris RD, Stoja E, Chin M (2018) Financial market volatility, macroeconomic fundamentals and investor sentiment. J Bank Financ 92:130-145

Chuang W-J, Ouyang L-Y, Lo W-C (2010) The impact of investor sentiment on excess returns: a Taiwan market cases. Int J Inf Manag Sci 21:13-28

Clarke RG, Statman M (1998) Bullish or bearish? Financ Anal J 54:63-72

Dash SR, Mahakud J (2013) Investor sentiment and stock returns: do industries matter? Margin J Appl Econ Res 7:315-349

De Long JB, Shleifer A, Summers LH, Waldmann RJ (1990) Noise trader risk in financial markets. J Polit Econ 98(4):703-738

DeBondt WF, Thaler R (1985) Does the stock market overreact? J Finance XL(3):793-805

Dickey DA, Fuller WA (1981) Likelihood ratio statistics for autoregressive time-series with a unit-root. Econometrica 49:1057-1072

Ding Z, Liu Z, Zhang Y, Long R (2017) The contagion effect of international crude oil price fluctuations on Chinese stock market investor sentiment. Appl Energy 187:27-36

Elton EJ, Gruber MJ, Busse JA (1998) Do investors care about sentiment? J Bus 71:477-500

Engle RF (1982) Autoregressive conditional heteroskedasticity with estimates of the variance of United Kingdom inflation. Econometrica 50:987-1007

Engle RF, Ng VK (1993) Measuring and testing the impact of news on volatility. J Financ 48:1749-1778

Fama EF (1965) The Behavior of Stock-Market Prices. J Bus 38(1):34-105

Fang L, Yu H, Huang Y (2018) The role of investor sentiment in the long-term correlation between US stock and bond markets. Int Rev Econ Financ 58:127-139

Finter P, Ruenzi S (2012) The impact of investor sentiment on the German stock market. Z Betriebswirt 82(2):133-163

Fisher KL, Statman M (2000) Investor sentiment and stock returns. Financ Anal J 56:16-23

Granger CWJ (1969) Inves ga g causal relations by econometric models and cross-spectral models. Econometrica 37:424-438

Gupta R (2019) Manager sentiment and stock market volatility. Journal of Manag Inf Decis Sci 22(1):11-21

Henderson BJ, Jegdeesh N, Weisbach MS (2006) World markets for raising new capital. J Financ Econ 82:63-101

Jiang F, Lee J, Martin X, Zhou G (2019) Manager sentiment and stock returns. J Financ Econ 132(1):126-149

Jones C (2001) A century of stock market liquidity and trading costs. Columbia University Mimeo, New York

Karpoff JM (1987) The relation between price changes and trading volume: a survey. J Financ Quant Anal 22(1):109-126

Kumari J, Mahakud J (2016) Investor sentiment and stock market volatility: evidence from India. J Asia Pac Bus 17(2):173-202

Lee WY, Jiang CX, Indro DC (2002) Stock market volatility, excess returns, and the role of investor sentiments. J Bank Financ 26:2277-2299

Lemmon M, Portniaguina E (2006) Consumer confidence and asset prices: some empirical evidence. Rev Financ Stud 19(4): 1499-1529

Li BH (2014) Does investor sentiment predict stock returns? The evidence from the Chinese stock market. J Syst Sci Complex 27:130-143

Mcleod Al, LI WK (1983) Diagnostic checking ARMA time series models using squared residual autocorrelations. J Time Ser Anal 4:269-273

Mushinada VNC, Veluri VSS (2018) Investors overconfidence behaviour at the Bombay Stock Exchange. Int J Manag Financ 14(5):613-632

Neal R, Wheatley SM (1998) Do measures of investor sentiment predict returns? J Financ Quant Anal 33(04):523-547

Qiang Z, Shue-e Y (2009) Noise trading, investor sentiment volatility, and stock returns. Syst Eng Theory Pract 29(3):40-47

Qiu L, Welch I (2006) Investor sentiment measures. In: Schmeling M (ed) Investor sentiment, herd-like behavior and stock returns http://ssrn.com/abstract $=589641$

Rahman ML, Shamsuddin A (2019) Investor sentiment and the price-earnings ratio in the G7 stock markets. Pac Basin Financ J 55:46-62

Sehgal S, Sood GS, Rajput N (2009) Investor sentiment in India: a survey. Vision: J Bus Perspect 13(2):13-23

Shiller RJ (1981) Do stock prices move too much to be justified by subsequent changes in dividends? Am Econ Rev 71(3): $421-436$

Sias RW, Starks LT, Tinic SM (2001) Is noise trader risk priced? J Financ Res 24:311-329

Verma R, Soydemir G (2009) The impact of individual and institutional investor sentiment on the market price of risk. Q Rev Econ Finance 49(3):1129-1145

Verma R, Verma P (2007) Noise trading and stock market volatility. J Multinatl Financ Manag 17:231-243

Wang YH, Keswani A, Taylor SJ (2006) The relationships between sentiment, returns and volatility. Int J Forecasting 22: 109-123

Wen F, Xu L, Ouyang G, Kou G (2019) Retail investor attention and stock price crash risk: Evidence from China. Int Rev Financ Anal 65:101376

Yang Y, Copeland L (2014) The effects of sentiment on market return and volatility and the cross-sectional risk premium of sentiment-affected volatility, Cardiff economics working papers, no. E2014/12. Cardiff Business School, Cardiff

Ying CC (1966) Stock market prices and volumes of sales. Econometrica 34:676-685

Zhou G (2018) Measuring investor sentiment. Ann Rev Financ Econ 10:239-259

Zhou L, Yang C (2019) Stochastic investor sentiment, crowdedness and deviation of asset prices from fundamentals. Econ Model 79:130-140

Zhu X (2012) Investor sentiment and volatility of stock index an empirical analysis from the perspective of behavioural finance. Adv Appl Econ Finance 3(4):627-629

\section{Publisher's Note}

Springer Nature remains neutral with regard to jurisdictional claims in published maps and institutional affiliations. 